\title{
Influências na estruturação de currículos de Arquivologia: as configurações acadêmico- institucionais, o contexto regional, 0 mercado laboral e o perfil docente
}

\section{Cíntia Aparecida Chagas Arreguy}

Professora Assistente do Curso de Arquivologia da Escola de Ciência da Informação (ECI) da Universidade Federal de Minas Gerais (UFMG). Mestre em Administração Pública pela Fundação João Pinheiro. Doutoranda em Ciência da Informação pela ECI/UFMG

Leandro Ribeiro Negreiros

Professor Assistente do Curso de Arquivologia da Escola de Ciência da Informação (ECI) da Universidade Federal de Minas Gerais (UFMG) até agosto de 2013. Analista Legislativo da Assembleia Legislativa do Estado de Minas Gerais (ALMG). Mestre em Ciência da Informação pela ECI/UFMG

Welder Antônio Silva

Professor Assistente do Curso de Arquivologia da Escola de Ciência da Informação (ECI) da Universidade Federal de Minas Gerais (UFMG). Mestre em Ciência da Informação pela UFF/IBICT. Doutorando em Ciência da Informação pela ECI/UFMG

http://dx.doi.org/10.1590/1981-5344/2344

Discute a influência das configurações acadêmicoinstitucionais, do mercado laboral, do contexto regional e do perfil docente das instituições de ensino na estruturação ou reestruturação curricular de cursos de graduação em Arquivologia. Apresenta questionário a ser utilizado para análise desses fatores como mais um 
instrumento para compor a metodologia de análise, avaliação e reestruturação curricular de cursos de Arquivologia, já trabalhada em Negreiros, Silva e Arreguy (2012; 2013). O questionário piloto foi testado com os dados do curso de graduação em Arquivologia da Escola de Ciência da Informação da Universidade Federal de Minas Gerais e os resultados constatam a importância dos dados analisados para um entendimento mais amplo da formação arquivística, principalmente no que se refere ao perfil do docente da área. A análise relativa ao contexto regional mostrou-se complexa, tendo em vista a dificuldade na obtenção dos dados, a capilaridade das fontes de informação oficiais e, principalmente, o desafio que é relacionar os dados obtidos com a realidade da formação curricular instalada.

Palavras-chave: Reestruturação curricular; Arquivologia; Metodologia; Perfil docente; Mercado laboral; Configurações acadêmico-institucionais.

\section{Influences in the structuring Archival Science curriculum: the academic- institutional settings, the regional context, the labor market and the teacher profile}

Discuss the influence of academic-institutional settings, labor market, the regional context and teacher profile of educational institutions in structuring or restructuring curriculum of undergraduate courses in Archival Science. Presents a questionnaire to be used for analysis of these factors as an additional instrument to compose the methodology of analysis, evaluation and curriculum restructuring Archival courses, already worked in Negreiros, Silva and Arreguy (2012; 2013). The questionnaire was tested with the data of the undergraduate course in Escola de Ciência da Informação of the Universidade Federal de Minas Gerais and verifies the importance of data analysis to a broader understanding of Archival formation, especially with regard to teacher profile in the area. The regional context analysis was complex, in view of the difficulty in obtaining data, the reach of the official information sources and, 
especially, the challenge is to relate the data obtained with the reality of installed curricular formation.

Keywords: Curriculum restructuring; Archival Science; Methodology; Teacher profile; Labor market; Academicinstitutional settings.

Recebido em 24.02.2015 Aceito em 31.03.2015

\section{Introdução}

O presente trabalho é uma continuidade de estudos iniciados em 2012, quando se apresentou uma metodologia para análise, avaliação e reestruturação curricular de cursos de Arquivologia, sustentada na construção de um mapa conceitual que esquematizava as necessidades teórico-práticas e as relações interdisciplinares de um curso de Arquivologia, com base na visão de renomados autores da área (NEGREIROS; SILVA; ARREGUY, 2012).

Em 2013, por consequência, nova etapa da pesquisa baseou-se no levantamento das disciplinas presentes nos currículos dos cursos de Arquivologia do Brasil e na classificação delas de acordo com categorias preestabelecidas em 2012. A análise apresentada objetivou subsidiar uma tentativa de harmonização curricular dos cursos de Arquivologia do Brasil. Os resultados deste último trabalho sugeriram que, para que os cursos de Arquivologia do Brasil estejam em harmonia, é necessário firmar acordos entre diversas instâncias: universidades, corpos docentes de cada curso, pares da área de arquivologia e outras (NEGREIROS; SILVA; ARREGUY, 2013).

Quando apresentada, na III Reunião de Ensino e Pesquisa em Arquivologia (REPARQ), em Salvador, a pesquisa de 2013 suscitou uma das recomendações do evento, segundo a qual seria necessário promover:

o desdobramento da pesquisa sobre harmonização curricular, selecionando e enviando aos cursos alguns pontos a serem discutidos com os Colegiados, a fim de ampliar o estudo, levando em conta a estrutura e especificidades de cada curso e o perfil docente daí decorrente. Os resultados dessa nova fase da pesquisa serão discutidos no Fórum Nacional de Ensino e Pesquisa em Arquivologia, durante o Congresso Nacional de Arquivologia, em 2014 (REPARQ, 2013).

A partir das discussões realizadas nesse evento, em Salvador, ficou evidente a preocupação de que não se poderia pensar em harmonização curricular dos cursos de Arquivologia do país sem se considerar o contexto regional, a capacidade docente da instituição, o mercado laboral e as configurações acadêmico-institucionais. Tornou-se claro que, embora haja 
um número de disciplinas que devem ser abrangidas por todos os currículos de Arquivologia do Brasil, outras tantas devem partir da percepção acurada dos fatores de influência citados.

Esta pesquisa, portanto, é uma tentativa de criar mais um instrumento para compor a metodologia de análise, avaliação e reestruturação curricular de cursos de Arquivologia, sob a perspectiva mais abrangente de se considerar não só as disciplinas inerentes a um curso dessa área, mas também as necessidades institucionais e regionais. O questionário que ora se apresenta foi testado na realidade do curso de graduação em Arquivologia da Escola de Ciência da Informação da Universidade Federal de Minas Gerais para, depois, ser ampliado, para os demais cursos existentes no país, como já se fez anteriormente.

Para alcançar o objetivo proposto, o artigo traz discussões sobre a estrutura e as especificidades de cada curso - que abrangem as configurações acadêmico-institucionais, o contexto regional e o mercado laboral - e do perfil docente. Ademais, apresenta-se o questionário elaborado para o levantamento de dados desses fatores, o piloto realizado na UFMG e as considerações sobre o teste desse instrumento.

\section{Estrutura e especificidade de cada curso}

Ao se discutir a estruturação ou reestruturação curricular de um curso de graduação, qual seja, o de Arquivologia, vários fatores devem ser levados em consideração. Acredita-se que esses fatores estejam relacionados, inicialmente, às necessidades teórico-práticas e às relações interdisciplinares inerentes a um curso de Arquivologia, amplamente discutidas em Negreiros, Silva e Arreguy (2012; 2013), trabalhos que estimularam a existência deste que se apresenta.

As discussões oriundas das pesquisas mencionadas acima alertaram para o fato de que a formação discente deve levar em conta, ainda, o contexto acadêmico em que os alunos estão inseridos e todas as características sociais, econômicas, geográficas e políticas que circundam o locus de formação. O currículo é, portanto, produto do meio em que é inserido e este local se expande, inclusive, para o entorno da unidade de ensino.

Além disso, há vários fatores que podem influenciar a formação do discente, não apenas o currículo, e que são, inclusive, determinantes dos conteúdos curriculares de cada curso.

É fundamental que se observem essas questões ao se pensar nas disciplinas ou na orientação que terá o currículo a ser operacionalizado em sala de aula. De forma contrária, o aluno teria uma formação alheia às necessidades locais do mercado e às expectativas sociais do contingente que rodeia o seu centro de formação. Além disso, sua instrução para o exercício da Arquivologia estaria desvinculada da tradição histórico-social e regional.

Não se encontraram estudos que realizassem essa abordagem de forma direta e completa. Portanto, fica claro que o trabalho que se 
apresenta é o resultado de uma reflexão inicial a respeito das influências locais que sofrem os cursos de Arquivologia e não afasta contribuições que visem completar esse aprendizado.

De maneira geral, categorizaram-se os fatores que influenciam a estruturação de um currículo e a definição da formação arquivística em duas classes, a saber:

a)configurações acadêmico-institucionais:

A expressão "configurações acadêmico-institucionais" foi utilizada por Tanus (2013), ao discutir as influências das instituições acadêmicas nas definições dos cursos de Arquivologia, Biblioteconomia e Museologia, e parece ser a mais adequada para reunir os fatores que interferem diretamente na construção do currículo.

Nesta categoria, podem ser arrolados aqueles fatores que possuem relação direta com a estruturação do curso de Arquivologia, ou seja, o locus de formação especificamente: a unidade de ensino e sua relação com a instituição de maneira geral; a categoria administrativa da instituição de ensino (público ou privada); a unidade de ensino e sua relação com os cursos nela ministrados, inclusive os de especialização, mestrado e doutorado; o ano de implantação do curso e, consequentemente, o seu tempo de existência; o órgão ao qual o curso está vinculado (departamento, instituto ou escola, entre outros); a existência de bibliotecas e laboratórios que atendam ao curso de Arquivologia e correlatos; e a existência de periódico(s) da instituição que publiquem material relacionado à área.

\section{b)contexto regional e mercado laboral:}

Como já dito, outras proximidades podem influenciar sobremaneira o curso a ser ministrado. Souza (2011, p. 118) trata da "vinculação do ensino com o mercado laboral", ou seja, da necessidade constante dos cursos se adaptarem às exigências do mercado que irá receber os egressos e do elo constante entre a construção ou a reformulação do currículo e as necessidades dos empregadores, para que haja uma harmonia entre a formação e o estabelecimento desses profissionais no mercado. Oliveira (2012) alerta sobre a atuação do arquivista:

No século $X X$, o arquivista ampliou os papéis que desempenhava. Além do papel que milenarmente exercia junto à administração pública e do papel de colaborador na análise e interpretação dos documentos históricos, pelo qual ficou conhecido no século XIX, o arquivista passou a trabalhar com os arquivos privados e os arquivos de empresa [...]. A separação entre arquivos históricos e arquivos correntes criou uma distinção artificial entre duas áreas que lidavam com o mesmo objeto de estudo e trabalho [...]. Neste momento, a Arquivística busca emergir da crise por meio da construção de um novo perfil profissional. Essa mudança depende, 
essencialmente, da renovação das competências profissionais e revisão dos modelos de formação. (OLIVEIRA, 2012, p. 104105).

A autora defende que a universidade não se submeterá às exigências do mercado de trabalho simplesmente, mas também não ficará alheia a essas realidades. A partir dos objetivos próprios e da autonomia que tem para encaminhá-los, a universidade definirá o que será mais adequado para a formação do profissional. Acrescenta:

O papel da universidade não se limita a fornecer profissionais para o mercado de trabalho. Entretanto, ela não pode ignorar as expectativas sociais. Assim como a Arquivística, a universidade também carece de remodelagem. Ela precisa se adaptar às demandas contemporâneas, em um momento em que as formações necessitam de uma abordagem mais ampla e menos tecnicista (OLIVEIRA, 2012, p. 120).

Essa relação entre o mercado laboral e a formação do discente se efetivará nas disciplinas que tratam dos chamados estágios supervisionados e ambos passarão a ser "espaços formativos" (COSTA, 2012). Assim: "[...] identificar a configuração do mundo do trabalho dos arquivistas e das suas diversas demandas profissionais nos remete à compreensão do contexto atual de atuação profissional e corrobora com as ações formativas dos futuros profissionais" (COSTA, 2012, p. 131).

Da mesma maneira, o contexto regional é relevante para a compreensão do local onde a formação será inserida e para o fornecimento de subsídios que a incrementarão.

Nessa categoria, podem constar: a proximidade com as instituições de ensino que possuam cursos de Arquivologia, as associações de classe ou os denominados coletivos profissionais; as instituições correlatas (arquivos, museus, bibliotecas e outros); as instituições públicas e as empresas privadas que poderiam assimilar os profissionais; os fatores econômicos, sociais, históricos e culturais relevantes para a área e a legislação local existente referente à temática.

\section{Perfil docente}

A fim de compreender as especificidades de cada um dos cursos de Arquivologia, este trabalho propõe uma análise do perfil dos respectivos corpos docentes. Tal estudo é fundamental para o entendimento da dinâmica do curso, pois se entende que o docente tem papel central na construção e na implementação do currículo escrito. Entende-se como docente do curso o professor efetivo que lecionou pelo menos uma disciplina obrigatória nos últimos quatro anos, período este que se refere, geralmente, ao tempo regular de uma graduação. A opção pelos professores responsáveis por disciplinas obrigatórias baseia-se na ideia de que a quase totalidade dos discentes formados no curso teria contato com 
tais profissionais que, em alguma medida, influenciariam a formação acadêmica dos alunos. Esses professores seriam os responsáveis pela operacionalização do currículo escrito na prática da sala de aula.

O mapeamento do perfil docente dos cursos de graduação em Arquivologia do Brasil terá como base a estrutura do currículo da Plataforma Lattes. Essa plataforma surgiu a partir das iniciativas de integração de currículos dos pesquisadores brasileiros realizadas pelo Conselho Nacional de Desenvolvimento Científico e Tecnológico (CNPq) e existentes desde a década de 1980 (CNPq, 2014).

Atualmente, a Plataforma Lattes proporciona a integração de bases de dados de currículos, grupos de pesquisa e de instituições em um sistema de informações. O Currículo Lattes:

[...] se tornou um padrão nacional no registro da vida pregressa e atual dos estudantes e pesquisadores do país, e é hoje adotado pela maioria das instituições de fomento, universidades e institutos de pesquisa do País. Por sua riqueza de informações e sua crescente confiabilidade e abrangência, se tornou elemento indispensável e compulsório à análise de mérito e competência dos pleitos de financiamentos na área de ciência e tecnologia (CNPq, 2014).

Alguns trabalhos já se dedicaram ao estudo do perfil docente. Entre aqueles relacionados à área de Arquivologia, destacam-se o de Marques (2007) e Marques e Roncaglio (2012). Na área de Ciência da Informação, foi encontrado um estudo de Daura e Galvão (2011). Em outra área de conhecimento, Vieira, Ensslin e Silva realizaram estudo significativo, publicado no ano de 2011.

O trabalho de Marques (2007) tem como foco a formação/titulação dos docentes dos nove cursos de Arquivologia existentes no Brasil no período da pesquisa. Foram levantadas as áreas de formação dos professores, nos níveis de graduação, mestrado e doutorado; a existência de programas de pós-graduação no departamento/faculdade/instituto ao qual o curso de Arquivologia está vinculado e a participação de docentes dos cursos de arquivologia nos respectivos programas.

No trabalho de Marques e Roncaglio (2012, p. 76), realizou-se um "mapeamento preliminar da configuração científica da Arquivologia no Brasil". Para o levantamento dos dados referentes aos docentes dos cursos de graduação em Arquivologia, a pesquisa baseou-se em um questionário estruturado e divulgado para o grupo de professores que participaram da I Reunião de Ensino e Pesquisa em Arquivologia (I REPARQ), realizada entre os dias 7 e 9 de junho de 2010, na Universidade de Brasília. Esse questionário deveria ser respondido pelos coordenadores dos cursos e se dividia em três partes: 1) Identificação da instituição; 2) Formação e produção científica dos docentes; 3) Produção na área de Arquivologia nos programas de pós-graduação. O questionário foi respondido por oito universidades, quais sejam: UNIRIO, UFSM, UnB, UEL, UFES, FURG, UFMG 
e UFAM, porém, foi necessária uma verificação nos Currículos Lattes da maioria dos docentes, diante das respostas incompletas e divergentes dos questionários. (MARQUES; RONCAGLIO, 2012, p. 76).

Esse trabalho apresenta dados referentes ao nível de formação e tabelas com dados quantitativos da produção científica dos docentes de cada um dos cursos analisados. A produção científica é dividida em livros; capítulos de livros; artigos em periódicos; comunicações em eventos. Constam, ainda, informações sobre as orientações realizadas pelos docentes no curso de Arquivologia e projetos de iniciação científica, destacando o número de trabalhos com temáticas específicas na área de Arquivologia. Outro aspecto apresentado pelas autoras é a atuação dos docentes em programas de pós-graduação dentro e fora das instituições a que estão vinculados. São apresentados ainda dados referentes à participação dos docentes em grupos de pesquisa.

O trabalho de Daura e Galvão (2011) apresenta um mapeamento da formação/titulação dos docentes dos cursos de graduação em Arquivologia, Biblioteconomia e Museologia de vinte e sete universidades púbicas brasileiras. A pesquisa teve a função de mapear "como a interdisciplinaridade no campo da Ciência da Informação se reflete na composição dos corpos docentes dos cursos de graduação de universidades públicas brasileiras" (DAURA; GALVÃO, 2011, p. 242). A coleta de dados foi realizada por meio de consulta aos sites institucionais dos cursos de graduação e ao Currículo Lattes dos docentes. Foram contatados os coordenadores dos cursos de graduação que não tinham sites institucionais, a fim de obter uma lista dos docentes integrantes do curso. Devido a dificuldades como a ausência de informações sobre os docentes nos sites institucionais e do Currículo Lattes de alguns docentes (62), além de outros 25 com Currículo Lattes incompleto, foram excluídos 87 perfis docentes e o estudo focalizou uma amostra de 417 perfis dos 504 inicialmente considerados.

Um trabalho considerado similar foi realizado por Vieira, Ensslin e Silva, publicado em 2011. Esse artigo é resultado de uma pesquisa sobre a produção científica dos docentes dos departamentos de contabilidade de três universidades federais do sul do Brasil, são elas: Universidade Federal de Santa Catarina (UFSC), Universidade Federal do Paraná (UFPR) e Universidade Federal do Rio Grande do Sul (UFRGS). Tal trabalho destaca a produção dos docentes nessas universidades, pois os considera como "patrimônio intelectual dessas instituições e, por isso, devem colaborar ativamente para a construção de conhecimento proposta por elas" (VIEIRA; ENSSLIN; SILVA, 2011, p. 45). A pesquisa teve como objetivos específicos:

(i) apontar os docentes mais prolíficos; (ii) apontar, em termos qualitativos, a produção científica dos docentes diante da classificação estipulada pelo Qualis/CAPES (triênio 20072009) e (iii) evidenciar as principais áreas de atuação dos docentes em termos de produção científica. (VIEIRA; ENSSLIN; SILVA, 2011, p. 46). 
O trabalho analisa a produção em periódicos e eventos. São analisadas as publicações das categorias trabalhos completos publicados em anais de congressos e artigos completos publicados em periódicos entre os anos de 2008 e 2009. Segundo os autores, a publicação nesses veículos cumpre a função de disseminar o conhecimento produzido pelo autor à comunidade científica. Os dados foram obtidos no Currículo Lattes dos docentes. Os resultados são apresentados na forma de quadros nominais por docente e universidade, com dados quantitativos de publicações em periódicos em congressos e quadros com pontuações dos docentes em relação aos critérios Qualis/CAPES. São apontados, ainda, os docentes mais produtivos de cada universidade, de acordo com o número de publicações e a pontuação de cada docente em relação aos critérios Qualis/CAPES. Os resultados apresentados revelam que a produção nas três universidades apresentadas concentra-se em um pequeno número de docentes.

Um aspecto de interseção desse trabalho de Vieira, Ensslin e Silva (2011) com o que ora se apresenta é o enquadramento temático das publicações dos docentes, visando compreender os vínculos entre esse enquadramento e os currículos dos cursos e as linhas de pesquisa de pósgraduação nas universidades a que os cursos estão vinculados.

O trabalho que se apresenta tem ligações com os estudos apresentados acima, mas se caracteriza por um maior detalhamento. A análise da produção docente tem como base a estrutura do Currículo Lattes, abrangendo os seguintes itens:

a) formação acadêmica nos níveis de Graduação, Especialização, Mestrado e Doutorado;

b) formação complementar;

c) atuação profissional na área de arquivos;

d) quantidade de projetos de pesquisa;

e) quantidade de projetos de extensão;

f) área em que leciona (ministra disciplinas);

g) áreas em que se sente preparado para lecionar (ministrar disciplinas)

h) livros publicados;

i) capítulos de livros publicados;

j) artigos publicados em periódicos;

k) trabalhos completos publicados em anais de eventos;

I) apresentações de trabalho e/ou Conferências;

m) produção técnica;

n)fluência em outros idiomas; 
o) membro de corpo editorial de periódico (Editor e/ou Parecerista).

Destaca-se que as produções enquadradas nos itens das letras c a $\mathrm{m}$ são classificadas de acordo com as categorias temáticas definidas na pesquisa e apresentadas em trabalho exposto na III Reunião de Ensino e Pesquisa em Arquivologia (REPARQ) no ano de 2012 (NEGREIROS; SILVA; ARREGUY, 2013), quais sejam:

a)Fundamentos da Arquivologia;

b)O profissional de arquivologia;

c)Gestão de documentos;

d)Gestão de documentos eletrônicos e digitais;

e)Arquivo permanente;

f)Preservação / conservação / restauração;

g)Planejamento e projetos arquivísticos;

h)Usuários;

i)Políticas e legislação arquivística;

j)Métodos e técnicas de pesquisa em arquivologia;

k)Temas diversos/tópicos - Arquivologia;

I)Interdisciplinar.

O principal diferencial do trabalho que se apresenta em relação às pesquisas citadas acima é que o questionário do perfil docente é baseado, quase em sua totalidade, na estrutura do Currículo Lattes dos professores. Muitos desses dados foram extraídos pelo professor diretamente do Currículo Lattes, ficando por conta de uma análise mais subjetiva apenas o enquadramento dos trabalhos nas categorias temáticas pré-definidas.

\section{Metodologia}

A construção do questionário apoia-se nos três vértices que sustentam esta pesquisa: a) as configurações acadêmico-institucionais; b) o mercado laboral e o contexto regional; e c) o perfil docente.

A primeira parte do questionário abrange as questões relacionadas ao perfil do curso, ou seja, orienta a busca pelos dados que se referem à descrição da instituição de ensino que abriga o curso de Arquivologia, o contexto regional e o mercado de trabalho que o representa. Grande parte dos dados podem ser encontrados nas publicações disponíveis no Instituto Brasileiro de Geografia e Estatística (IBGE) ${ }^{1}$.

A segunda parte do questionário, por sua vez, trata das questões relacionadas ao perfil dos professores que lecionam disciplinas

\footnotetext{
${ }^{1}$ Disponível em: <http://www.ibge.gov.br>. Acesso em: 1 set. 2014.
} 
obrigatórias no curso de Arquivologia a ser analisado nos últimos quatro anos. Grande parte dos dados analisados nesta seção pode ser encontrada nos Currículos Lattes dos docentes, disponíveis no site do $\mathrm{CNPq}^{2}$.

O curso de Arquivologia da Escola de Ciência da Informação da Universidade Federal de Minas Gerais foi escolhido pela proximidade dos autores com a instituição e como forma de colaborar com a reestruturação curricular por que passa este curso. De qualquer forma, o levantamento apresentado é um teste da ferramenta elaborada e poderá ser aprimorado após a análise dos colaboradores da área.

Os resultados obtidos serão apresentados considerando-se, primeiro, a análise do instrumento como contribuidor para a metodologia de análise, avaliação e reestruturação curricular de cursos de Arquivologia. Em seguida, os dados coletados pela ferramenta também serão analisados, como forma de se exercitar e explicitar as possibilidades do levantamento.

\section{Resultados}

Os resultados serão apresentados levando-se em consideração, inicialmente, o perfil dos docentes do curso e, em seguida, as configurações acadêmico-institucionais da UFMG, o contexto regional e o mercado-laboral disponível.

\subsection{O perfil dos docentes do curso de Arquivologia da UFMG}

Para o desenvolvimento da pesquisa, foram considerados os docentes que ministraram disciplinas obrigatórias no Curso de Arquivologia da UFMG no período compreendido entre $1^{\circ}$ de janeiro de 2010 e 31 de dezembro de 2013. Após levantamento junto ao colegiado do curso, chegou-se à amostra de 18 docentes. Todos eles $(100 \%)$ responderam ao questionário disponibilizado on-line, entre os dias 11 de setembro de 2014 e 10 de outubro de 2014.

Em relação ao perfil dos docentes do Curso de Arquivologia da UFMG, os dados demonstram o que segue.

Quanto à graduação, as formações são variadas - conforme pode ser observado na Figura 1 Erro! Fonte de referência não encontrada.. Destaca-se que, na categoria "Outra", encontram-se os seguintes cursos: Artes com habilitação em Cinema (1), Ciências Sociais (2), Comunicação Social (1), Engenharia (1), Psicologia (2) e Serviço Social (1). Os demais profissionais são graduados em áreas comumente afins à Arquivologia no cenário brasileiro: História (6), Biblioteconomia (2) e Ciência da Computação / Análise de Sistema (1). Ressalta-se que há apenas um docente graduado em Arquivologia. Todavia, em contrapartida, nove docentes (50\%) já atuaram ou atuam em arquivos, dois deles, inclusive,

\footnotetext{
${ }^{2}$ Disponível em: <http://www.cnpq.br/>. Acesso em: 1 set. 2014.
} 
por períodos longos: 17 e 18 anos. Isso demonstra que boa parte dos docentes, apesar de não ter formação específica, tem vivência na área, possui experiências práticas e capacidade de correlacionar prática e teoria (dimensão epistemológica X dimensão pragmática da Arquivologia).

O docente que possui graduação em Arquivologia formou-se em outro estado da Federação. Este fato é condizente com o contexto regional, pois o primeiro curso de graduação em Arquivologia de Minas Gerais é o da UFMG, que formou sua primeira turma no ano de 2012. Acredita-se que a necessidade de deslocamento do profissional é um dificultador para sua inserção no curso. Isso porque a área também carece de maiores possibilidades de pós-graduação para o egresso, pois, no Brasil, somente existe um curso de Mestrado em Arquivologia, implantado no ano de 2012.

Figura 1 - Formação do docente do curso de Arquivologia da UFMG

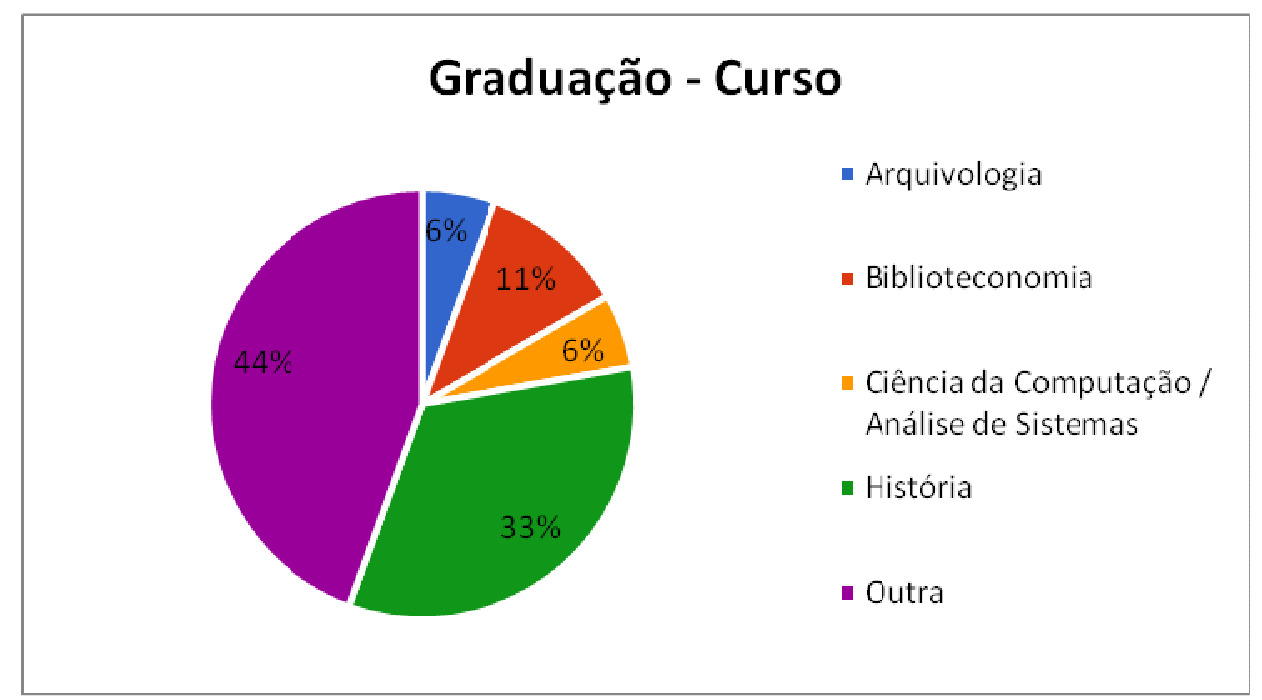

(graduação)

Fonte: Dados da pesquisa

Entre os docentes que já atuaram ou atuam em arquivos, destacase que $2(11 \%)$ tiveram/têm a oportunidade de trabalhar com arquivos de instituições públicas federais; 6 (33\%), com arquivos de instituições públicas estaduais; 4 (22\%), com arquivos de instituições públicas municipais; 2 (11\%), com arquivos de pessoa jurídica privada com fins lucrativos; e 1 (6\%), com arquivos de pessoa jurídica sem fins lucrativos. Nesse caso, pode-se afirmar um conhecimento específico e prático-laboral em relação a quase todos os tipos de instituições mantenedoras e produtoras de arquivos, exceto arquivos de pessoa física e arquivos familiais.

Em relação à experiência e vivência prático-laboral, cabe destacar que 5 desses docentes (28\%) tiveram/têm oportunidade de lidar com arquivos correntes; 5 (28\%) tiveram/têm oportunidade de lidar com arquivos intermediários; e 7 (39\%) atuaram/atuam junto a arquivos permanentes, cobrindo, portanto, as três fases documentais, bem como 
as principais rotinas, procedimentos e especificidades da área. Em relação à vivência e experiência prático-laboral dos docentes do curso de Arquivologia da UFMG, é importante observar a Tabela 1 - Vivência e experiência prático-laboral abaixo:

Tabela 1 - Vivência e experiência prático-laboral

\begin{tabular}{l|c|c}
\hline \multicolumn{1}{c|}{ Rotinas e ou procedimentos } & $\begin{array}{c}\text { Quantidade } \\
\text { de docentes }\end{array}$ & $\begin{array}{c}\text { Porcentagem } \\
\text { de docentes }\end{array}$ \\
\hline \hline Produção & 3 & $17 \%$ \\
\hline Tramitação / uso & 5 & $28 \%$ \\
\hline Classificação & 5 & $28 \%$ \\
\hline Avaliação & 7 & $39 \%$ \\
\hline Transferência & 3 & $17 \%$ \\
\hline Recolhimento & 6 & $33 \%$ \\
\hline Eliminação & 5 & $28 \%$ \\
\hline Arranjo & 6 & $33 \%$ \\
\hline Descrição & 5 & $28 \%$ \\
\hline Preservação & 3 & $17 \%$ \\
\hline Disseminação e acesso & 7 & $39 \%$ \\
\hline Elaboração e/ou manutenção de Sistema & 4 & $22 \%$ \\
Informatizado & 4 & \\
\hline
\end{tabular}

Fonte: Dados da pesquisa.

É importante destacar que alguns desses docentes assumiram cargos de direção e um deles declarou que já coordenou projetos de captação de recursos em órgãos de fomento (por meio das leis federal e estadual de incentivo à cultura).

Ainda em relação à experiência e vivência prático-laboral, observase que tais docentes as adquiriram lidando com todos os gêneros documentais, conforme pode ser observado na tabela abaixo:

Tabela 2 - Experiência com os gêneros documentais

\begin{tabular}{l|c|c}
\hline \multicolumn{1}{c|}{ Gênero documental } & $\begin{array}{c}\text { Quantidade } \\
\text { de } \\
\text { docentes }\end{array}$ & $\begin{array}{c}\text { Porcentage } \\
\mathbf{m} \text { de } \\
\text { docentes }\end{array}$ \\
\hline Textual & 8 & $44 \%$ \\
\hline Filmográfico & 3 & $17 \%$ \\
\hline Sonoro & 3 & $17 \%$ \\
\hline Iconográfico & 5 & $28 \%$ \\
\hline Cartográfico & 3 & $17 \%$ \\
\hline Micrográfico & 3 & $17 \%$ \\
\hline Informático (digital) & 2 & $11 \%$ \\
\hline
\end{tabular}

Fonte: Dados da pesquisa.

Retornando à formação dos docentes do curso de Arquivologia da UFMG, em relação aos locais de graduação, mais da metade estudou na própria UFMG: 10 dos 18, o que totaliza $56 \%$ do corpo docente. Apenas o professor graduado em Arquivologia concluiu seu curso em instituição localizada fora do Estado de Minas Gerais. 
Constatou-se que 56\% fizeram um curso de especialização (Figura 2 - Formação do docente do curso de Arquivologia da UFMG), 100\% fizeram um curso de mestrado (Erro! Fonte de referência não encontrada.Erro! Fonte de referência não encontrada.), $78 \%$ possuem o título de doutor e $17 \%$ estão em processo de doutoramento (Erro! Fonte de referência não encontrada.Erro! Fonte de referência não encontrada.).

Figura 2 - Formação do docente do curso de Arquivologia da UFMG (especialização)

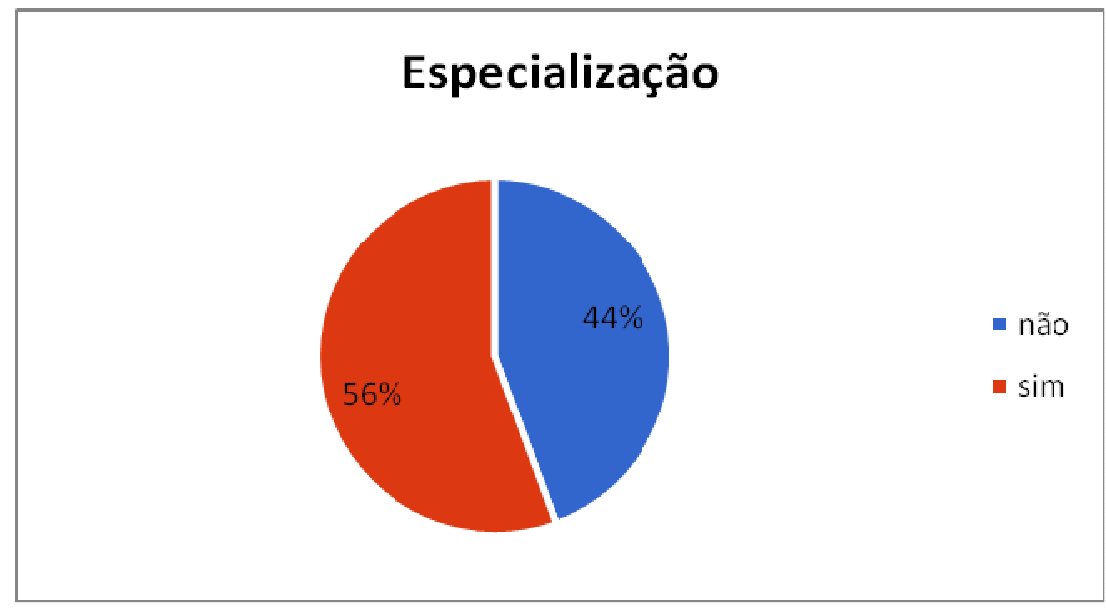

Fonte: Dados da pesquisa.

Figura 3 - Formação do docente do curso de Arquivologia da UFMG (mestrado)

Fonte: Dados da pesquisa. 
Figura 4 - Formação do docente do curso de Arquivologia da UFMG (doutorado)

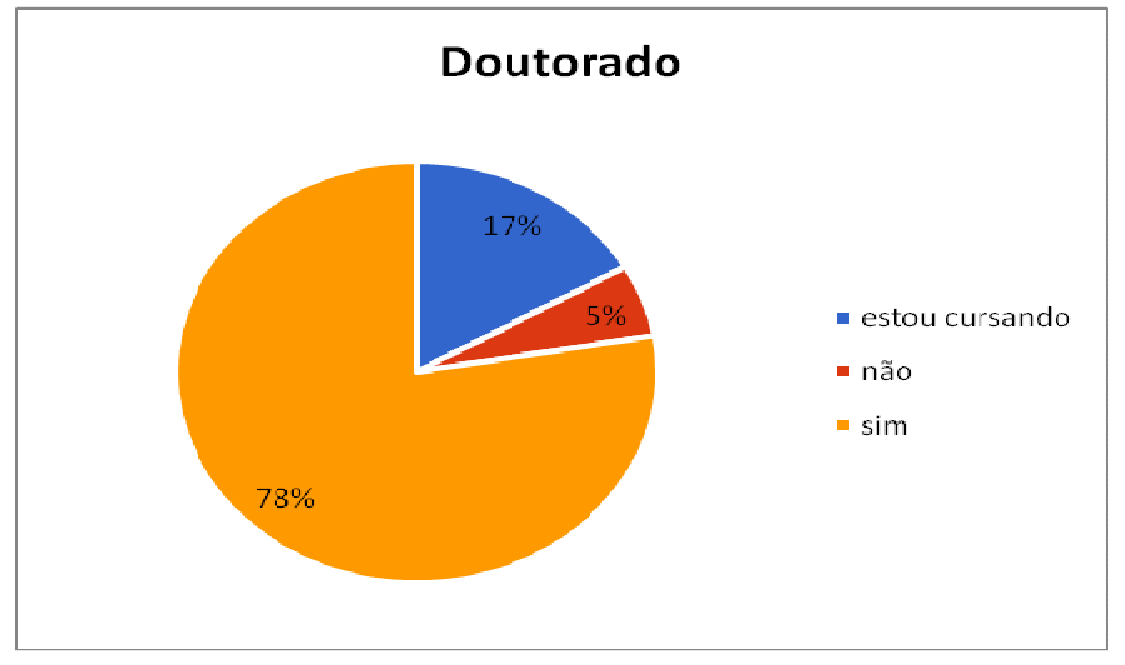

Fonte: Dados da pesquisa.

Em relação aos cursos de especialização concluídos, observa-se que estão compreendidos cursos específicos em relação à Arquivologia (Arquivos Públicos e Organização de Arquivos: 2 docentes); alguns em áreas afins (Gestão da Informação e Inteligência Competitiva, Informática e Inteligência Artificial, Planejamento Estratégico e Sistemas de Informação); e interdisciplinares (Administração, Engenharia de Software, Sociologia, Teoria e Método em Ciências Sociais). Tal constatação demonstra tanto um grau de aprofundamento e especialização em questões arquivísticas, quanto uma possibilidade de ampliação de vivências, experiências e desenvolvimento de projetos interdisciplinares. Em relação aos cursos de mestrado concluídos, ressalta-se que o quadro se mostra variado, com um destaque moderado em Ciência da Informação $(33 \%$ dos docentes)

e em

História

(17\%) 
Influências na estruturação de currículos de Arquivologia: as configurações acadêmico-institucionais, o contexto regional, o mercado laboral e o perfil docente

Figura
Cíntia Aparecida Chagas Arreguy; Leandro Ribeiro Negreiros; Welder Antônio Silva 
Figura 5 - ). Esse fenômeno também demonstra uma possibilidade de ampliação de vivências, experiências e desenvolvimento de projetos interdisciplinares. Foi possível observar, ainda, que $17(94,4 \%)$ têm mestrado nas grandes áreas do conhecimento: Ciências Humanas e Ciências Sociais Aplicadas. Neste quesito, é importante reforçar que o primeiro programa de pós-graduação no nível de mestrado e com foco em Arquivologia no cenário brasileiro foi criado recentemente. 
Figura 5 - Mestrado (áreas)

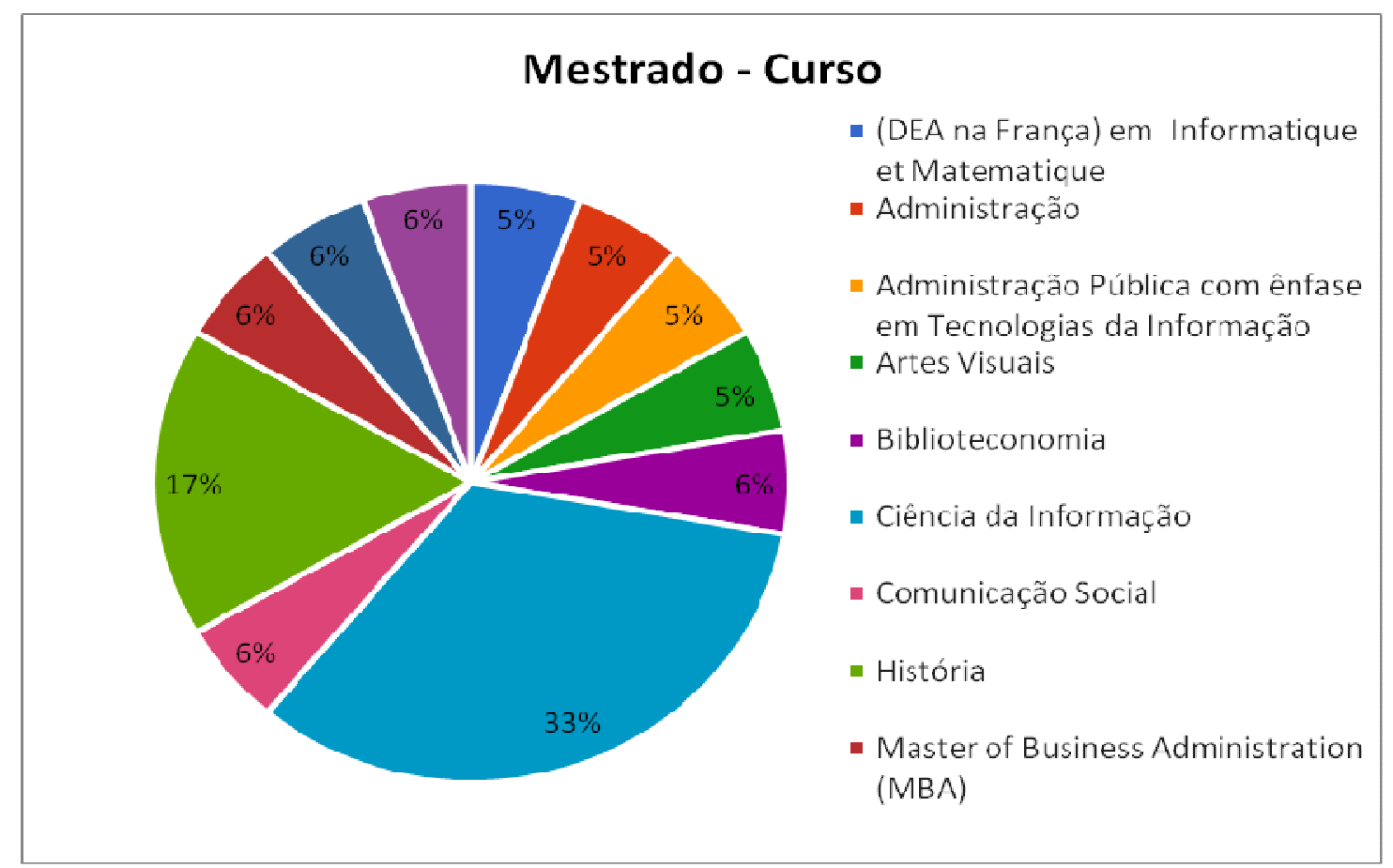

Fonte: Dados da pesquisa.

Em relação aos cursos de doutorado concluídos e em andamento, o quadro se repete em relação à variabilidade, porém com um destaque um pouco mais acentuado em Ciência da Informação (41\%), seguido de um destaque em Educação, História da Educação (juntos somam 17\%) e em História (12\%). Neste quesito, considera-se importante o número de docentes que direcionaram suas pesquisas de doutoramento para a área de Educação, uma vez que isso demonstra aperfeiçoamento e interesse pela prática pedagógica. Aqui também é importante destacar que o Brasil, até o momento, não possui nenhum programa de pós-graduação no nível de doutorado com foco em Arquivologia, o que, de certa forma, justifica e explica a procura por programas em áreas afins e/ou interdisciplinares. 
Figura 6 - Doutorado (áreas)

\section{Doutorado - Curso}

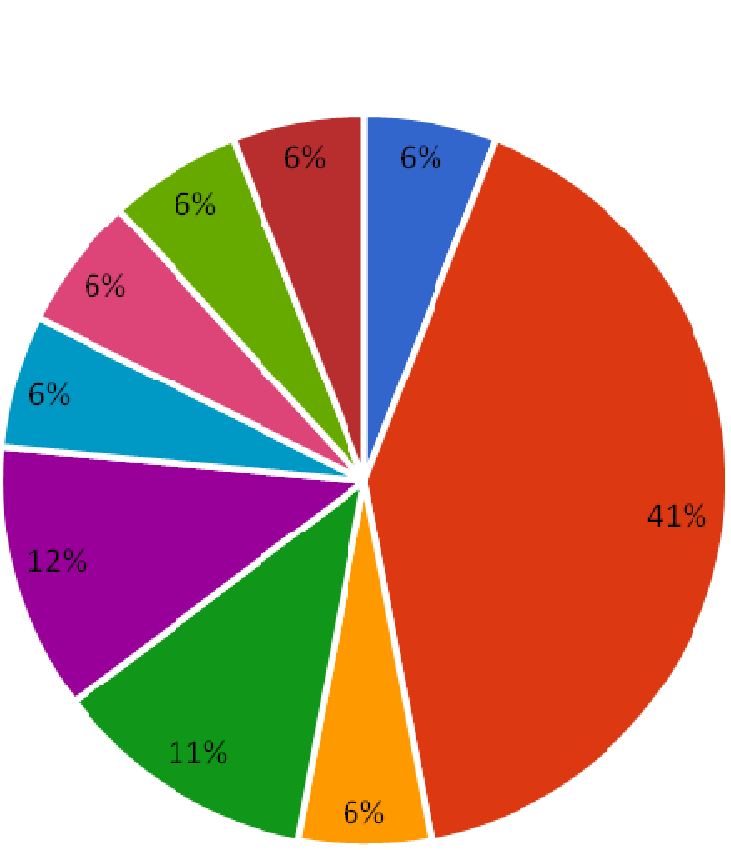

- Administração

- Ciência da Informação

- Ciências (concentraçăo: Antropologia Social)

- Educação

- História

- História da educação

- Informática, Anal. Sistemas e Tratamento de Sinal. Título: OPenRT - Reseaux de Petri pour la Modelisation des Applications Temps Reel

- Psicologia Social e do Trabalho

- Sociologia

Fonte: Dados da pesquisa.

Ainda em relação à formação dos docentes, foi possível observar que, apesar de muitos terem feito seus cursos de especialização, mestrado e doutorado em instituições diversas, inclusive no âmbito internacional, as graduações, em sua maioria, foram concluídas no âmbito da UFMG, o que demonstra, de algum modo, endogenia. Ressalta-se, ainda, que tais cursos foram realizados desde a década de 70 até os dias atuais ( 3 docentes estão em processo de doutoramento), o que demonstra um certo grau de renovação e atualização ao longo do tempo.

Foi possível observar que boa parte dos docentes atuam em programas de pós-graduação stricto-sensu e lato-sensu (78\%) (Figura 7 ). Tais programas compreendem áreas afins e/ou interdisciplinares à Arquivologia, tais como: Ciência da Informação, Gestão do Patrimônio, Gestão Estratégica da Informação, Gestão e Arquitetura da Informação, Gestão da Informação e Pessoas, História, Patrimônio, e Cultura, Contabilidade e Controladoria. Destaca-se que um dos docentes já atuou 
em uma pós-graduação (lato-sensu) cujo foco são os arquivos - Gestão de Arquivos e Documentos.

Figura 7 - Participação em programas de pós-graduação

\section{Participação em Programa de Pós-graduação}

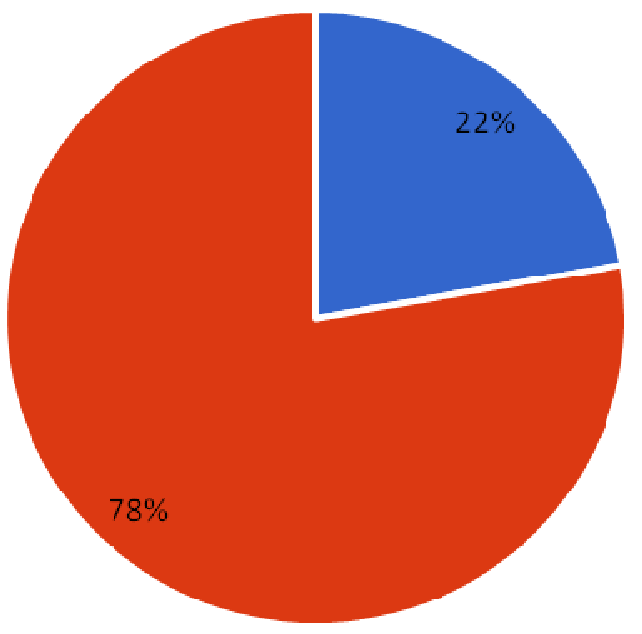

Fonte: Dados da pesquisa.

É relevante mencionar que 14 docentes (78\%) são ou foram membros de corpo editorial de periódicos (editor, conselho consultivo e/ou parecerista $a d-h o c)$ no período compreendido entre $1^{\circ}$ de janeiro de 2010 e 31 de dezembro de 2013. Tal participação ocorre/ocorreu tanto em periódicos especializados em Arquivologia, quanto em periódicos especializados em áreas afins e/ou interdisciplinares (inclusive no âmbito internacional), tais como: Ciência da Informação, Gestão e Conhecimento, Semântica, Ontologia e Engenharia, Ciência da Computação, Cultura, Administração, História, Patrimônio, Antropologia e Arquitetura e Urbanismo.

Em relação à área em que lecionam (ministram disciplinas na graduação), o quadro é, de certa forma, equilibrado - exceto em relação aos conteúdos interdisciplinares (11 docentes, ou seja, 61\%) e temas diversos/tópicos em Arquivologia (7 docentes, ou seja 39\%) - e compreende todas as categorias consideradas pelos autores em momentos anteriores (NEGREIROS; SILVA; ARREGUY, 2012; 2013), conforme demonstrado na tabela abaixo: 
Tabela 3 - Disciplinam que lecionam (categorias)

\begin{tabular}{l|c|c}
\hline \multicolumn{1}{c|}{ Categorias } & $\begin{array}{c}\text { Quantidade } \\
\text { de docentes }\end{array}$ & $\begin{array}{c}\text { Porcentagem } \\
\text { de docentes }\end{array}$ \\
\hline 01 Fundamentos da Arquivologia & 4 & $22 \%$ \\
\hline 02 O Profissional de Arquivologia & 2 & $11 \%$ \\
\hline 03 Gestão de documentos & 4 & $22 \%$ \\
\hline 04 Gestão de documentos eletrônicos e digitais & 1 & $6 \%$ \\
\hline 05 Arquivo Permanente & 3 & $17 \%$ \\
\hline 06 Conservação / preservação / restauração & 3 & $17 \%$ \\
\hline 07 Planejamento e projetos arquivísticos & 6 & $33 \%$ \\
\hline 08 Usuários & 4 & $22 \%$ \\
\hline 09 Políticas e legislação arquivística & 4 & $22 \%$ \\
\hline 10 Métodos e técnicas de pesquisa em & 3 & $17 \%$ \\
arquivologia & 7 & $39 \%$ \\
\hline 11 Temas diversos / tópicos em Arquivologia & 11 & $61 \%$ \\
\hline Interdisciplinar & &
\end{tabular}

Fonte: Dados da pesquisa.

Quando questionados sobre as áreas nas quais se sentem preparados para lecionar, o cenário anterior praticamente se repete:

Tabela 4 - Disciplinam que poderiam lecionar (categorias)

\begin{tabular}{l|c|c}
\hline \multicolumn{1}{c|}{ Categorias } & $\begin{array}{c}\text { Quantidade } \\
\text { de docentes }\end{array}$ & $\begin{array}{c}\text { Porcentagem } \\
\text { de docentes }\end{array}$ \\
\hline 01 Fundamentos da Arquivologia & 5 & $28 \%$ \\
\hline 02 O Profissional de Arquivologia & 4 & $22 \%$ \\
\hline 03 Gestão de documentos & 4 & $22 \%$ \\
\hline 04 Gestão de documentos eletrônicos e digitais & 4 & $22 \%$ \\
\hline 05 Arquivo Permanente & 4 & $22 \%$ \\
\hline 06 Conservação / preservação / restauração & 3 & $17 \%$ \\
\hline 07 Planejamento e projetos arquivísticos & 7 & $39 \%$ \\
\hline 08 Usuários & 4 & $22 \%$ \\
\hline 09 Políticas e legislação arquivística & 6 & $33 \%$ \\
\hline 10 Métodos e técnicas de pesquisa em & 9 & $50 \%$ \\
arquivologia & 7 & $39 \%$ \\
\hline 11 Temas diversos / tópicos em Arquivologia & 8 & $44 \%$ \\
\hline Interdisciplinar & &
\end{tabular}

Fonte: Dados da pesquisa.

Em relação às duas tabelas anteriores


Tabela 3 - e Tabela 4 - ), observa-se a concentração em categorias mais genéricas em relação à área de Arquivologia, como planejamento e projetos, métodos e técnicas, políticas e legislação e temas diversos/tópicos. Em relação ao número elevado de docentes que lecionam e/ou se sentem preparados para lecionar conteúdos interdisciplinares, tal fenômeno merece atenção e cuidado, pois, se, por um lado, é positivo e salutar haver vários docentes habilitados a ministrar determinada disciplina, por outro lado, isso pode acarretar uma dispersão do curso e pouca possibilidade de aprofundamento na Arquivologia.

Em relação aos projetos (de extensão e de pesquisa) em desenvolvimento e/ou desenvolvidos pelos docentes e suas produções (livros, capítulos de livros, artigos de periódicos, trabalhos completos publicados em anais de eventos, apresentações de trabalhos e/ou conferências e produções técnicas), o cenário é o seguinte:

Tabela 5 - Projetos e produções (parte 1$)^{3}$

\begin{tabular}{|c|c|c|c|c|c|c|}
\hline & $\begin{array}{c}01 \\
\begin{array}{c}01 \\
\text { Fundamentos } \\
\text { da }\end{array} \\
\text { Arquivologia }\end{array}$ & $\begin{array}{c}020 \\
\text { profissional } \\
\text { de } \\
\text { arquivologia }\end{array}$ & $\begin{array}{l}03 \text { Gestão de } \\
\text { documentos }\end{array}$ & $\begin{array}{l}04 \text { Gestão de } \\
\text { documentos } \\
\text { eletrônicos e } \\
\text { digitais }\end{array}$ & $\begin{array}{l}05 \text { Arquivo } \\
\text { permanente }\end{array}$ & $\begin{array}{c}06 \\
\text { Preservação / } \\
\text { conservação / } \\
\text { restauração }\end{array}$ \\
\hline $\begin{array}{l}\text { Projetos de } \\
\text { pesquisa }\end{array}$ & $\begin{array}{l}12 \text { projetos } \\
6 \text { docentes }\end{array}$ & $\begin{array}{c}3 \text { projetos } \\
2 \text { docentes }\end{array}$ & $\begin{array}{l}11 \text { projetos } \\
7 \text { docentes }\end{array}$ & $\begin{array}{c}6 \text { projetos } \\
3 \text { docentes }\end{array}$ & $\begin{array}{l}7 \text { projetos } \\
4 \text { docentes }\end{array}$ & $\begin{array}{c}5 \text { projetos } \\
2 \text { docentes }\end{array}$ \\
\hline $\begin{array}{l}\text { Projetos de } \\
\text { extensão }\end{array}$ & $\begin{array}{c}5 \text { projetos } \\
2 \text { docentes }\end{array}$ & $x x x$ & $\begin{array}{c}6 \text { projetos } \\
5 \text { docentes }\end{array}$ & $\begin{array}{l}2 \text { projetos } \\
2 \text { docentes }\end{array}$ & $\begin{array}{c}6 \text { projetos } \\
3 \text { docentes }\end{array}$ & $\begin{array}{l}5 \text { projetos } \\
2 \text { docentes }\end{array}$ \\
\hline $\begin{array}{c}\text { Livros } \\
\text { publicados }\end{array}$ & $\begin{array}{c}3 \text { livros } \\
2 \text { docentes }\end{array}$ & $\begin{array}{c}1 \text { livro } \\
1 \text { docente }\end{array}$ & $\begin{array}{c}1 \text { livro } \\
1 \text { docente }\end{array}$ & $\begin{array}{c}2 \text { livros } \\
1 \text { docente }\end{array}$ & $\begin{array}{c}7 \text { livros } \\
3 \text { docentes }\end{array}$ & $\begin{array}{c}3 \text { livros } \\
1 \text { docente }\end{array}$ \\
\hline $\begin{array}{l}\text { Capítulos de } \\
\text { livros }\end{array}$ & $\begin{array}{l}15 \text { capítulos } \\
3 \text { docentes }\end{array}$ & $\begin{array}{l}4 \text { capítulos } \\
2 \text { docente }\end{array}$ & $\begin{array}{l}4 \text { capítulos } \\
1 \text { docente }\end{array}$ & $\begin{array}{l}1 \text { capítulo } \\
1 \text { docente }\end{array}$ & $\begin{array}{l}9 \text { capítulos } \\
5 \text { docentes }\end{array}$ & $\begin{array}{l}4 \text { capítulos } \\
1 \text { docente }\end{array}$ \\
\hline $\begin{array}{l}\text { Artigos de } \\
\text { periódicos }\end{array}$ & $\begin{array}{c}+15 \text { artigos } \\
1 \text { docente }\end{array}$ & $\begin{array}{c}1 \text { artigo } \\
1 \text { docente }\end{array}$ & $\begin{array}{l}3 \text { artigos } \\
1 \text { docente }\end{array}$ & $\begin{array}{c}3 \text { artigos } \\
1 \text { docente }\end{array}$ & $\begin{array}{c}5 \text { artigos } \\
3 \text { docentes }\end{array}$ & $\begin{array}{c}4 \text { artigos } \\
3 \text { docentes }\end{array}$ \\
\hline $\begin{array}{l}\text { Trabalhos } \\
\text { completos } \\
\text { publicados } \\
\text { em anais de } \\
\text { eventos }\end{array}$ & $\begin{array}{l}14 \text { trabalhos } \\
4 \text { docentes }\end{array}$ & $\begin{array}{l}5 \text { trabalhos } \\
3 \text { docentes }\end{array}$ & $\begin{array}{l}8 \text { trabalhos } \\
3 \text { docentes }\end{array}$ & $\begin{array}{l}3 \text { trabalhos } \\
1 \text { docente }\end{array}$ & $\begin{array}{l}13 \text { trabalhos } \\
5 \text { docentes }\end{array}$ & $\begin{array}{l}8 \text { trabalhos } \\
2 \text { docentes }\end{array}$ \\
\hline $\begin{array}{c}\text { Apresentaçõe } \\
\text { s de trabalhos } \\
\text { e/ou } \\
\text { conferências }\end{array}$ & $\begin{array}{c}15 \\
\text { apresentações } \\
5 \text { docentes }\end{array}$ & $\begin{array}{c}6 \\
\text { apresentações } \\
4 \text { docentes }\end{array}$ & $\begin{array}{c}9 \\
\text { apresentações } \\
4 \text { docentes }\end{array}$ & $\begin{array}{c}2 \\
\text { apresentações } \\
1 \text { docente }\end{array}$ & $\begin{array}{c}15 \\
\text { apresentações } \\
4 \text { docentes }\end{array}$ & $\begin{array}{c}7 \\
\text { apresentações } \\
2 \text { docentes }\end{array}$ \\
\hline $\begin{array}{l}\text { Produções } \\
\text { técnicas }\end{array}$ & $\begin{array}{c}8 \text { produções } \\
4 \text { docentes }\end{array}$ & $\begin{array}{l}1 \text { produção } \\
1 \text { docente }\end{array}$ & $\begin{array}{c}+ \text { de } 6 \\
\text { produções } \\
2 \text { docentes }\end{array}$ & $\begin{array}{l}1 \text { produção } \\
1 \text { docente }\end{array}$ & $\begin{array}{c}\text { + de } 8 \\
\text { produções } \\
2 \text { docentes }\end{array}$ & $\begin{array}{c}\quad+\text { de } 8 \\
\text { produções } \\
2 \text { docentes }\end{array}$ \\
\hline
\end{tabular}


Influências na estruturação de currículos de Arquivologia: as configurações acadêmico-institucionais, o contexto regional, o mercado laboral e o perfil docente
Cíntia Aparecida Chagas Arreguy; Leandro Ribeiro Negreiros; Welder Antônio Silva

Tabela 6 - Projetos e produções (parte 2$)^{3}$

\begin{tabular}{|c|c|c|c|c|c|c|}
\hline & $\begin{array}{c}07 \\
\text { Planejamento } \\
\text { e projetos } \\
\text { arquivísticos }\end{array}$ & 08 Usuários & $\begin{array}{l}09 \text { Políticas } \\
\text { e legislação } \\
\text { arquivística }\end{array}$ & $\begin{array}{c}10 \text { Métodos } \\
\text { e técnicas } \\
\text { de pesquisa } \\
\text { em } \\
\text { arquivologia }\end{array}$ & $\begin{array}{c}11 \text { Temas } \\
\text { diversos/tópico } \\
\mathrm{s}-\text { Arquivologia }\end{array}$ & Interdiscipli-nar \\
\hline $\begin{array}{l}\text { Projetos de } \\
\text { pesquisa }\end{array}$ & $\begin{array}{l}7 \text { projetos } \\
4 \text { docentes }\end{array}$ & $\begin{array}{l}5 \text { projetos } \\
3 \text { docentes }\end{array}$ & $\begin{array}{l}8 \text { projetos } \\
5 \text { docentes }\end{array}$ & $\begin{array}{l}5 \text { projetos } \\
2 \text { docentes }\end{array}$ & $\begin{array}{l}9 \text { projetos } \\
4 \text { docentes }\end{array}$ & $\begin{array}{l}12 \text { projetos } \\
8 \text { docentes }\end{array}$ \\
\hline $\begin{array}{l}\text { Projetos de } \\
\text { extensão }\end{array}$ & $\begin{array}{l}8 \text { projetos } \\
5 \text { docentes }\end{array}$ & $\begin{array}{l}6 \text { projetos } \\
3 \text { docentes }\end{array}$ & $\begin{array}{l}8 \text { projetos } \\
4 \text { docentes }\end{array}$ & $\begin{array}{l}5 \text { projetos } \\
2 \text { docentes }\end{array}$ & $\begin{array}{l}5 \text { projetos } \\
2 \text { docentes }\end{array}$ & $\begin{array}{c}3 \text { projeto } \\
3 \text { docentes }\end{array}$ \\
\hline $\begin{array}{c}\text { Livros } \\
\text { publicados }\end{array}$ & $\begin{array}{c}3 \text { livros } \\
1 \text { docente }\end{array}$ & $x x x$ & $\begin{array}{c}5 \text { livros } \\
3 \text { docentes }\end{array}$ & $\begin{array}{c}3 \text { livros } \\
1 \text { docente }\end{array}$ & $x x x$ & $\begin{array}{c}4 \text { livros } \\
2 \text { docentes }\end{array}$ \\
\hline $\begin{array}{l}\text { Capítulos de } \\
\text { livros }\end{array}$ & $\begin{array}{l}6 \text { capítulos } \\
2 \text { docentes }\end{array}$ & $\begin{array}{l}4 \text { capítulos } \\
2 \text { docentes }\end{array}$ & $\begin{array}{l}10 \text { capítulos } \\
3 \text { docentes }\end{array}$ & $\begin{array}{l}5 \text { capítulos } \\
2 \text { docentes }\end{array}$ & $x x x$ & $\begin{array}{l}\text { + de } 13 \\
\text { capítulos } \\
6 \text { docentes }\end{array}$ \\
\hline $\begin{array}{l}\text { Artigos de } \\
\text { periódicos }\end{array}$ & $\begin{array}{c}3 \text { artigos } \\
2 \text { docentes }\end{array}$ & $\begin{array}{l}2 \text { artigos } \\
1 \text { docente }\end{array}$ & $\begin{array}{c}4 \text { artigos } \\
2 \text { docentes }\end{array}$ & $\begin{array}{l}2 \text { artigos } \\
1 \text { docente }\end{array}$ & $\begin{array}{c}1 \text { artigo } \\
1 \text { docente }\end{array}$ & $\begin{array}{c}\text { + de } 27 \text { artigos } \\
6 \text { docentes }\end{array}$ \\
\hline $\begin{array}{l}\text { Trabalhos } \\
\text { completos } \\
\text { publicados } \\
\text { em anais de } \\
\text { eventos }\end{array}$ & $\begin{array}{l}12 \text { trabalhos } \\
4 \text { docentes }\end{array}$ & $\begin{array}{l}11 \text { trabalhos } \\
3 \text { docentes }\end{array}$ & $\begin{array}{l}8 \text { trabalhos } \\
4 \text { docentes }\end{array}$ & $\begin{array}{l}7 \text { trabalhos } \\
3 \text { docentes }\end{array}$ & $x x x$ & $\begin{array}{c}+ \text { de } 35 \\
\text { trabalhos } \\
6 \text { docentes }\end{array}$ \\
\hline $\begin{array}{l}\text { Apresentaçõ } \\
\text { es de } \\
\text { trabalhos } \\
\text { e/ou } \\
\text { conferências }\end{array}$ & $\begin{array}{c}12 \\
\text { apresentações } \\
5 \text { docentes }\end{array}$ & $\begin{array}{c}+ \text { de } 15 \\
\text { apresentaçõe } \\
\text { s } \\
4 \text { docentes }\end{array}$ & $\begin{array}{c}13 \\
\text { apresentaçõe } \\
\text { s } \\
5 \text { docentes }\end{array}$ & $\begin{array}{c}6 \\
\text { apresentaçõe } \\
s \\
3 \text { docentes }\end{array}$ & $\begin{array}{l}1 \text { apresentação } \\
1 \text { docente }\end{array}$ & $\begin{array}{c}+ \text { de } 41 \\
\text { apresentações } \\
9 \text { docentes }\end{array}$ \\
\hline $\begin{array}{l}\text { Produções } \\
\text { técnicas }\end{array}$ & $\begin{array}{c}+ \text { de } 14 \\
\text { produções } \\
3 \text { docentes }\end{array}$ & $\begin{array}{l}3 \text { produções } \\
1 \text { docente }\end{array}$ & $\begin{array}{c}+ \text { de } 7 \\
\text { produções } \\
2 \text { docentes }\end{array}$ & $\begin{array}{c}+ \text { de } 8 \\
\text { produções } \\
2 \text { docentes }\end{array}$ & $\begin{array}{l}6 \text { produções } \\
3 \text { docentes }\end{array}$ & $\begin{array}{c}\text { + de } 21 \\
\text { produções } 5 \\
\text { docentes }\end{array}$ \\
\hline
\end{tabular}

Fonte: Dados da pesquisa.

Em relação à capacidade dos docentes de ler, produzir e falar em outros idiomas, o cenário é o seguinte:

\section{Tabela 7 - Idiomas}

\begin{tabular}{l|c|c|c}
\hline & $\begin{array}{l}\text { Lê (razoavelmente ou } \\
\text { perfeitamente) }\end{array}$ & $\begin{array}{l}\text { Fala } \\
\text { (razoavelmente ou } \\
\text { perfeitamente) }\end{array}$ & $\begin{array}{l}\text { Escreve } \\
\text { (razoavelmente } \\
\text { perfeitamente) }\end{array}$ \\
\hline Inglês & $89 \%$ & $72 \%$ & $56 \%$ \\
\hline Espanhol & $100 \%$ & $56 \%$ & $39 \%$ \\
\hline Francês & $72 \%$ & $28 \%$ & $28 \%$ \\
\hline Italiano & $17 \%$ & $6 \%$ & $6 \%$ \\
\hline
\end{tabular}

Fonte: Dados da pesquisa.

Observações:

1 - Um(a) projeto/produção pode contemplar mais de uma categoria.

2 - O formulário de coleta de dados não previu os projetos e produções em parcerias (+ de 1 docente envolvido).Dessa forma, um(a) projeto/produção pode ter sido contabilizado mais de uma vez.

3 - No formulário de coleta de dados, havia os seguintes limites nas opções: livros, de nenhum até + de 5 ; capítulos de livros, de nenhum até + de 5; artigos, de nenhum até + de 10 ; trabalhos, de nenhum até + de 10 ; apresentações, de nenhuma até + de 10; produções técnicas, de nenhuma até + de 5 . Em função desses limites, na totalização de alguns itens, foram utilizados os termos "+ de".

4 - Para facilitar a análise do leitor, foram negritadas, em cada item, as categorias que sobressaíram Observase, na

Tabela 5 - , que todas as categorias são contempladas. Destaca-se o volume de projetos/produções na categoria Fundamentos de Arquivologia, que sobressaiu nos itens projetos de pesquisa, capítulos de livros e artigos de periódicos, fato este que pode representar uma busca pelos docentes de maior compreensão e envolvimento com o desenvolvimento do quadro epistemológico da Arquivologia. Em contrapartida, ressalta-se que a categoria interdisciplinar sobressaiu em quase todos os itens. Neste caso, mais uma vez é importante reforçar que tal fenômeno merece atenção e cuidado, pois, se, por um lado, é positivo e salutar, por outro lado, pode acarretar uma dispersão e pouca possibilidade de aprofundamento na Arquivologia. 
Neste caso dos idiomas, considera-se o cenário positivo, uma vez que boa parte dos docentes tem capacidade de ler em outros idiomas, não se limitando apenas à literatura nacional; fala outros idiomas, o que possibilita a interação com profissionais de outros países e participação em eventos internacionais; e escreve em outro idiomas, o que permite a interação com profissionais de outras nacionalidades e a submissão de produções no cenário internacional.

\subsection{As configurações acadêmico-institucionais da UFMG, o contexto regional e o mercado-laboral disponível}

Institucionalmente, o curso de Arquivologia da UFMG está vinculado a uma unidade de ensino cujo nome faz referência à grande área, da tabela de conhecimento da Capes, Ciências Sociais Aplicadas, e à área Ciência da

Informação: Escola de Ciência da Informação (ECI). Na instituição em questão, também estão abrigados os cursos de graduação em Biblioteconomia e Museologia, ou seja, cursos afins e/ou interdisciplinares.

A ECI possui biblioteca própria e seu acervo bibliográfico específico em Arquivologia é considerado regular, uma vez que o quantitativo de títulos e exemplares ainda deixa a desejar. A unidade também abriga 3 cursos de especialização (Gestão Estratégica da Informação, Gestão e Arquitetura da Informação e Gestão de Informação e Pessoas)e 1 programa de pós-graduação (mestrado e doutorado) em Ciência da Informação. Como se percebe, os alunos, após terem concluído a graduação, encontram na própria instituição a possibilidade de continuarem seus estudos e atividades acadêmicas.

A ECI edita dois periódicos: Perspectiva em Ciência da Informação e Múltiplos Olhares em Ciência da Informação. Essas duas publicações apresentam avaliação Qualis: A1 e B5, respectivamente. Além dos periódicos editados pela unidade, no município de Belo Horizonte e proximidades, há mais três periódicos cujo escopo pode atender à Arquivologia: Revista do Arquivo Público Mineiro, Revista Fonte e Revista Eletrônica do Arquivo Público da Cidade de Belo Horizonte. Nesse sentido, observa-se que existe um cenário positivo para a produção científica, inclusive na própria unidade.

A ECI possui atualmente 2 laboratórios: Laboratório de Preservação de Acervos (LPA) e Laboratório da Tecnologia de Informação (LTI). Como se percebe, esses espaços possibilitam a condução de aulas teóricopráticas em quesitos importantes para a Arquivologia.

No município e em cidades próximas ao local onde o curso foi implantado, não há instituições arquivísticas federais. Em contrapartida, a região possui 1 instituição arquivística pública estadual e 1 municipal. Tal fato apresenta um cenário que proporciona o desenvolvimento de convênios, parcerias, estágios de alunos, visitas técnicas e, até mesmo, possibilidades de inserção no mercado laboral. 
No estado de Minas Gerais, existe a Associação Mineira de Arquivistas (AMArq), que congrega arquivistas e possibilita aos formandos e alunos apoio em relação às suas demandas e expectativas, por intermédio de um grupo profissional organizado.

O município de Belo Horizonte, onde se situa o curso de Arquivologia da UFMG, bem como o Estado de Minas Gerais possuem economias concentradas no setor de serviços. Segundo os últimos dados estatísticos colhidos pelo IBGE$^{4}$, os valores do PIB de ambos são os seguintes:

Tabela 8 - PIB

\begin{tabular}{l|c|c|c}
\hline & Agropecuária & Indústria & Serviços \\
\hline Belo Horizonte & 197 & 7.796 .245 & $\mathbf{3 8 . 2 6 8 . 5 3 8}$ \\
\hline Minas Gerais & 15.568 .048 & 50.306 .183 & $\mathbf{9 7 . 3 9 8 . 8 2 0}$ \\
\hline
\end{tabular}

Fonte: IBGE (2014).

Diante do exposto, observa-se que o setor de serviços apresenta a maior empregabilidade. Consequentemente, 0 arquivista teria mais oportunidades de trabalho. Vale ressaltar que o setor industrial está mais concentrado no entorno e no interior do Estado e, por ter uma participação importante na economia, apresenta-se também como uma possibilidade de mercado laboral.

Belo Horizonte obteve, em 2010, o Índice de Desenvolvimento Humano (IDH) acima da média nacional, 0,810. Este valor equivale à classificação destinada a países com desenvolvimento humano muito alto ${ }^{5}$. No Brasil, o município de Belo Horizonte está na $35^{a}$ posição em relação ao índice em questão. Destaca-se que o IDH mede a expectativa de vida ao nascer (possibilidade de uma vida longa e saudável), educação (acesso ao conhecimento) e Produto Interno Bruto (PIB) per capita (padrão de vida decente). Esse dado sugere que, em função da qualidade de vida oferecida, pode existir uma tendência de fixação dos egressos do curso no município e proximidades.

\section{Considerações finais}

Os resultados amplamente discutidos neste trabalho foram apresentados no encontro do grupo de Ensino e Pesquisa em Arquivologia, ocorrido em outubro de 2014, no VI Congresso Nacional de Arquivologia (CNA), em Santa Maria. Percebeu-se, a partir das discussões dos pares, a possibilidade de uma análise mais genérica, que abranja os demais cursos do país, para que seja possível comparar as influências das configurações

4 Disponível em: <http://cidades.ibge.gov.br/painel/painel.php?lang=\&codmun=310620\&search=minasgerais|belo-horizonte|infograficos:-dados-gerais-do-municipio>. Acesso em: 15 out. 2014.

${ }^{5}$ A classificação orienta-se pela seguinte forma:

- 25\% de menor IDH: desenvolvimento humano baixo (geralmente países pobres);

- 25\% acima dos de menor IDH: desenvolvimento humano médio (geralmente países em processo de desenvolvimento);

- 25\% abaixo dos países de melhor IDH: desenvolvimento humano alto (geralmente países em rápido processo de crescimento econômico - emergentes);

- 25\% de melhor IDH: desenvolvimento humano muito alto (geralmente países ricos e bem desenvolvidos). 
acadêmico-institucionais, do mercado laboral e do perfil docente das instituições de ensino na estruturação ou reestruturação curricular de cursos de graduação em Arquivologia.

Ficou clara, pelos resultados apresentados e pela apreciação do grupo, a importância dos dados analisados para um entendimento mais amplo da formação arquivística, principalmente no que se refere ao perfil do docente da área. Além disso, com a coleta de dados ampliada, será possível melhorar o conhecimento de como a formação em Arquivologia tem se estruturado no Brasil e de quem são os professores que ensinam Arquivologia no país.

A análise relativa ao contexto regional mostrou-se complexa, tendo em vista a dificuldade na obtenção dos dados, a capilaridade das fontes de informação oficiais e, principalmente, o desafio que é relacionar os dados obtidos com a realidade da formação curricular instalada. De qualquer forma, a análise é importante para estruturar ou reestruturar currículos, mas ficou evidente que pouco se poderá extrair quando se comparar dados dos contextos regionais dos demais cursos do país.

A partir da análise dos contextos regionais, restaram algumas dúvidas: regiões mais ricas têm mais cursos de Arquivologia? Regiões com PIB mais alto ou com IDH acima da média do país têm capacidade de absorver melhor os egressos? Como esses índices podem influenciar a formação do aluno de Arquivologia? Regiões que possuem suas economias concentradas no setor de serviços devem estruturar o currículo do curso de Arquivologia de forma diferente daquelas que têm a economia baseada na agricultura? É necessário que o tratamento desses dados seja avaliado em outra oportunidade de reunião entre pesquisadores da área para que possam ser melhor utilizados na pesquisa, uma vez que, de alguma maneira, influenciam a formação do discente. Além disso, é preciso pensar em parceria com outras áreas do conhecimento para que essa análise seja melhor conduzida e aprofundada com a especificidade que merece.

Os instrumentos testados cumpriram a função de auxiliar a metodologia de análise, avaliação e reestruturação curricular de cursos de Arquivologia, sob a perspectiva mais abrangente de se considerar não só as disciplinas inerentes a um curso dessa área, mas também as necessidades institucionais e regionais. Acredita-se, assim, que a recomendação da III REPARQ foi alcançada, ou seja, novos pontos foram incorporados à discussão de harmonização curricular e o estudo da formação em Arquivologia foi ampliado pelas questões da estrutura e especificidade da unidade de ensino e do perfil docente. 


\section{Referências}

CONSELHO NACIONAL DE DESENVOLVIMENTO CIENTÍFICO E TECNOLÓGICO (CNPq). Sobre a plataforma. 2014. Disponível em: <http://lattes.cnpq.br/>. Acesso em: 21 jul. 2014.

COSTA, L. C. Entre a formação e o trabalho: o arquivista diante das novas demandas sociais e organizacionais em matéria de informação. In: RODRIGUES, G. M.; COSTA, M. G. da. Arquivologia: configurações da pesquisa no Brasil - epistemologia, formação, preservação, uso e acesso. Brasília: Editora Universidade de Brasília, 2012. p. 125-150.

DAURA, A. P.; GALVÃO, M. C. B. O perfil docente e a interdisciplinaridade: estudando os cursos de graduação do campo da Ciência da Informação no Brasil. Revista Edicic, v. 1, n. 3, p. 229-247, jul./set. 2011. Disponível em: <http://www.edicic.org/revista/>. Acesso em: 21 jul. 2014.

\section{INSTITUTO BRASILEIRO DE GEOGRAFIA ESTATÍSTICA (IBGE). Cidades. 2014. Disponível em: < http://cidades.ibge.gov.br/painel/painel.php?lang =\&codmun=310620\&s earch=minas-gerais /belo-horizonte|infograficos:-dados-gerais-do- municipio>. Acesso em: 15 out. 2014.}

INSTITUTO BRASILEIRO DE GEOGRAFIA ESTATÍSTICA (IBGE). Indicadores sociais municipais: uma análise dos resultados do universo do Censo Demográfico 2010. Brasília: IBGE, 2011. Disponível em: <http://biblioteca.ibge.gov.br/visualizacao/livros/liv54598.pdf>. Acesso em: 15 out. 2014.

MARQUES, A. A. da C. Os espaços e dos diálogos da formação e configuração da arquivística como disciplina no Brasil. 2007. 298f. Dissertação (Mestrado em Ciência da Informação) - Universidade de Brasília, Brasília, 2007.

MARQUES, A. A. da C.; RONCAGLIO, C. A pesquisa científica em arquivologia no Brasil. In: MARIZ, A. C. A.; JARDIM, J. M.; SILVA, S. C. de A. (Orgs.). Novas dimensões da pesquisa e do ensino da Arquivologia no Brasil. Rio de Janeiro: Móbile; Associação dos Arquivistas do Estado do Rio de Janeiro, 2012.

NEGREIROS, L. R.; SILVA, W. A.; ARREGUY, C. A. C. Metodologia para análise, avaliação e reestruturação curricular de cursos de Arquivologia: a experiência do curso de Arquivologia da Escola de Ciência da Informação da Universidade Federal de Minas Gerais. In: CONGRESSO NACIONAL DE ARQUIVOLOGIA, 5., Salvador, 2012. Anais... Salvador, 2012. Disponível em: <http://www.enara.org.br/cna2012/anais/>. Acesso em: 9 out. 2013.

NEGREIROS, L. R.; SILVA, W. A. ; ARREGUY, C. A. C. Da Arquivologia que fazemos para a Arquivologia que queremos: mapeamento dos currículos 
dos cursos de Arquivologia no Brasil. In: REUNIÃO BRASILEIRA DE ENSINO E PESQUISA EM ARQUIVOLOGIA, 3., Salvador, 2013. [No prelo].

OLIVEIRA, H. de. A formação do arquivista na Universidade de Brasília e as habilidades profissionais demandadas pelo mercado de trabalho da capital federal. In: RODRIGUES, G. M.; COSTA, M. G. da. Arquivologia: configurações da pesquisa no Brasil - epistemologia, formação, preservação, uso e acesso. Brasília: Editora Universidade de Brasília, 2012. p. 99-123.

REUNIÃO DE ENSINO E PESQUISA EM ARQUIVOLOGIA (REPARQ), 3., Salvador, 2013. Perfil, evolução e perspectivas do ensino e da pesquisa em Arquivologia no Brasil: recomendações e moções. [Salvador, 2013]. [No prelo].

SOUZA, K. I. M. de. Arquivista, visibilidade profissional: formação, associativismo e mercado de trabalho. Brasília: Starprint, 2011.

TANUS, G. F. de S. C. Cenário acadêmico-institucional dos cursos de Arquivologia, Biblioteconomia e Museologia do Brasil. 242f. 2013. Dissertação (Mestrado em Ciência da Informação) - Programa de PósGraduação em Ciência da Informação, Escola de Ciência da Informação, Universidade Federal de Minas Gerais, Belo Horizonte, 2013.

VIEIRA, A. M.; ENSSLIN, S. R.; SILVA, H. A. S. da. Perfil da produção científica dos docentes dos departamentos de contabilidade de três universidades federais do sul do Brasil. Ref. Cont. UEM -Paraná, v. 30, n. 3, p. 44-59, set./dez. 2011. 